\title{
Washings and cryoprotectants for the production of Tilapia Surimi
}

\author{
Dayse Lícia de OLIVEIRA $^{1 *}$, Thiago Luís Magnani GRASSI ${ }^{1}$, Edson Francisco do Espirito SANTO², \\ Jefferson Felipe CAVAZZANA ${ }^{1}$, Marcelo Tacconi de Siqueira MARCOS ${ }^{1}$, Elisa Helena Giglio PONSANO ${ }^{1}$
}

\begin{abstract}
This research aimed at studying the effects of different washing conditions (distilled water $\mathrm{x}$ distilled water $+\mathrm{NaHCO}_{3}+$ $\mathrm{NaCl})$ and cryoprotectants $(\mathrm{NaCl}+$ saccharose $\mathrm{x}$ sorbitol + sodium tripolyphosphate) for the production of tilapia surimi. The experiment used a factorial design $2 \times 2$ and the variables analyzed were proximate composition, non-nitrogen protein (NNP) removal, texture, color and yield. The protein and moisture contents of the surimi were influenced neither by washings nor by cryoprotectants, while the ash content was higher when $\mathrm{NaCl}+$ saccharose were used as the cryoprotectants and the yield was higher when only distilled water was used for the washings. Combining distilled water for the washings and $\mathrm{NaCl}$ + saccharose as the cryoprotectants provided the highest lipid and NNP removals. The different treatments produced surimi gels with similar colors and texture.
\end{abstract}

Keywords: fish; proteins; texture; color.

Practical Application: Method of production of surimi.

\section{Introduction}

Fish is considered a valuable source of protein in the diets of many countries (Burger, 2008), representing $17 \%$ of the world`s animal protein intake and $6.7 \%$ of all the protein ingested by the population (Food and Agriculture Organization, 2016). According to FAO (Food and Agriculture Organization, 2016), the world fish consumption per capita increased from $9.9 \mathrm{~kg}$ in the 1960 's to $19.7 \mathrm{~kg}$ in 2013, reaching the record level of $20 \mathrm{~kg}$ in 2014, and aquaculture has come to comply with this increasing demand (Lem et al., 2014).

Fish may undergo several industrial operations and processes aiming at preservation, so retaining quality and increasing shelf life (Food and Agriculture Organization, 2016) and still providing products with distinguished functional properties, like surimi, that comprises the fish myofibrillar proteins recovered through various step-by-step processes including washing, dewatering, refining, mixing with cryoprotectants and freezing (Park, 2014).

Surimi is made from minced fish flesh, providing opportunities to use underutilized species with little or no commercial value, fish too small to undergo a processing method or residues from the industrialization (Martín-Sánchez et al., 2009; Barreto \& Beirão, 1999), so obtaining a value-added product despite of minimizing wastes and reducing environmental impacts.

Washings are of great importance for the final quality of the surimi, since they increase the concentration of the myofibrillar proteins, so improving the ability to gel formation (Belibagli et al., 2003; Lee, 1984). The use of cryoprotectants for the surimi production is important to keep the gel stability during freezing and thawing (Kuhn \& Soares, 2002). They avoid the proteins denaturation during freezing by binding water and proteins and support the gel structure after thawing by diminishing the intermolecular aggregation of the proteins (Ogawa \& Maia, 1999).

So, the choice for appropriate production methods and ingredients is of importance to provide a good quality surimi and improve the economics of the process. The purpose of this study was to check the effects of different kinds of washings and cryoprotectants for surimi production on the quality properties of the product.

\section{Materials and methods}

\subsection{Fish muscle and experimental design}

The experiment used a completely randomized design in a factorial scheme $2 \times 2$, in which the factors were the washings (distilled water $\mathrm{x}$ distilled water $+\mathrm{NaHCO}_{3}+\mathrm{NaCl}$ ) and the cryoprotectants $(\mathrm{NaCl}+$ saccharose $\mathrm{x}$ sorbitol + sodium tripolyphosphate), totaling four treatments (Table 1). Trims of farmed tilapia (Oreochromis niloticus) obtained after the filleting operation and maintained at $-20^{\circ} \mathrm{C}$ were used for the preparation of the surimis.

\subsection{Surimi preparation}

After thawing at $5^{\circ} \mathrm{C}$ for $24 \mathrm{~h}$, the fish fillet trims were ground, weighed and divided in two basins to receive the distinct washing waters. Three washing cycles (Table 1) were accomplished with water : muscle at $3: 1,6^{\circ} \mathrm{C}$ and 5 min of gentle stirring followed 
by $5 \mathrm{~min}$ of rest. After each washing cycle, the water was drained through a $100 \%$ polyester bag with vigorous manual wringing until no more water appeared.

The washed and drained muscle from each kind of washing was divided in two portions and added of two distinct combinations of cryoprotectants (Table 1) and cassava starch at $10 \%$. Washed muscles and ingredients were mixed to originate four distinct surimis. Four replicates of each preparation were performed, so originating 16 samples that were used for the analyses of yield, non-nitrogen protein and proximate composition. The kinds and amounts of chemicals used for the washings, well as the cryoprotectants, were stablished based on literature data (Barreto \& Beirão, 1999; Fogaça et al., 2015). The surimi samples were packed in plastic films and frozen at $-20^{\circ} \mathrm{C}$ until the gel preparation.

\subsection{Yield, non-nitrogen protein and proximate composition}

The yield of the treatments (\%) was calculated by the ratio between the weight of the raw muscle used and the weight of the final surimi. Non-nitrogen protein (NNP) was analyzed by micro Kjeldahl in the filtrate obtained after the precipitation of the surimi proteins with trichloroacetic acid at $15 \%$ (Horwitz \& Latimer JR, 2006). Moisture was analyzed at $105^{\circ} \mathrm{C}$, ash was analyzed at $550^{\circ} \mathrm{C}$ and crude protein was quantified by micro Kjeldhal ( $\mathrm{N}$ x 6.25) (Horwitz \& Latimer, 2006). Lipids were extracted and quantified following Folch methodology (Folch et al., 1957). All the analyses were performed in duplicates.

\subsection{Gel preparation}

In order to obtain a gel, the surimi samples were defrosted at $5{ }^{\circ} \mathrm{C}$ for $24 \mathrm{~h}$, manually filled into $24 \mathrm{~mm}$ diameter cellulose cases, tied and cooked at $90^{\circ} \mathrm{C} / 30 \mathrm{~min}$ in a water bath. After removing the cases, the gels were maintained at $5{ }^{\circ} \mathrm{C}$ for the color and texture analyses.

\subsection{Instrumental color analysis}

The CIEL $a b$ color ( $L=$ lightness, $a=$ red/green, $b=$ yellow/blue) of the gels was accomplished with a portable MiniScan XE Plus equipment (Hunterlab) calibrated with white and black standards, using $10^{\circ}$ for the observer angle and illuminant D65. The measurements were performed in triplicate at distinct but close sites on a slice of the gel removed from the inner portion of the product and the mean values were considered.

Table 1. Treatments used for the production of tilapia surimi.

\begin{tabular}{ccc}
\hline & \multicolumn{2}{c}{ Washings } \\
\cline { 2 - 3 } Cryoprotectants $^{1}$ & $\begin{array}{c}\text { 3 washings with } \\
\text { distilled water }\end{array}$ & $\begin{array}{c}1^{\text {st }} \text { washing - 5\%, NaHCO } \\
2^{\text {nd }} \text { and 3 }{ }^{\text {rd }} \text { washings - 3\% } \\
\text { NaCl }\end{array}$ \\
\hline $\mathrm{C} 1$ & Treatment 1 (T1) & Treatment 3 (T3) \\
$\mathrm{C} 2$ & Treatment 2 (T2) & Treatment 4 (T4) \\
\hline${ }^{1} \mathrm{C} 1=2 \% \mathrm{NaCl}+1 \%$ Saccharose and $\mathrm{C} 2=5 \%$ Sorbitol + 3\% Sodium tripolyphosphate.
\end{tabular}

${ }^{1} \mathrm{C} 1=2 \% \mathrm{NaCl}+1 \%$ Saccharose and $\mathrm{C} 2=5 \%$ Sorbitol $+3 \%$ Sodium tripolyphosphate.

\subsection{Texture profile analysis (TPA)}

TPA was accomplished with a Stable Micro System TAXT2 Texture Analyzer. Compression was performed with a stainless steel flat-bottomed $25 \mathrm{~mm}$ diameter cylindrical probe speeding $2.0 \mathrm{~mm} / \mathrm{s}$ before and after the measurement. The distance from the platform was $10 \mathrm{~mm}$. The parameters investigated were hardness, fracturability, adhesiveness, viscosity, cohesiveness, chewiness and resilience. Tests were performed in triplicate on standardized slices of the inner portion of the surimi and the mean values were considered.

\subsection{Statistical analysis}

ANOVA was used to analyze the data obtained from the chemical, yield and color analyses and the means were compared by Tukey's test. TPA data were analyzed by the non parametric Kruskal-Wallis test. The analyses were conducted using the procedures of SAS (Statistical Analysis System, version 9.3) at $5 \%$ significance.

\section{Results and discussion}

\subsection{Proximate composition, NNP and yield}

Surimi moisture can be influenced by the number of washings, since excessive washing may cause losses of myofibrillar proteins, well as by the cryoprotectants, since they have the ability to bind free water (Ogawa \& Maia, 1999). Additionally, moisture can be affected by the presence of salts and metal ions in the washing solution because they interfere in the formation of hydrogen bounds between proteins and water (Vaz, 2005). Nevertheless, in this study, no influence of the washing conditions or cryoprotectants occurred on the moisture content of the surimis (Table 2). Moreover, this result also reflects the standardization of the draining operation, although it was manually made.

Moisture contents ranging from 74 to $78 \%$ were described for the surimis of horse mackerel (Trachurus Trachurus) and hake (Merluccius Merluccius), respectively (Alvarez-Parrilla et al., 1997) and are in accordance with the values found in this experiment. Fogaça et al. (2015) found 75.44\% moisture for the surimi made of Nile tilapia filleting residues performing three washings with distilled cold water and adding $2 \% \mathrm{NaCl}$ and $1 \%$ saccharose.

The use of $\mathrm{NaCl}$ and saccharose as the cryoprotectors (T1 and T3) significantly increased the ash content of the surimi (Table 2), probably due to the retention of some salt in the product. The ash contents in the surimis from T2 and T4 are close to the $0.46 \%$ found by Kirschnik \& Macedo-Viegas (2009) for the surimi produced with tilapia using $0.1 \%$ sodium erythorbate and $0.5 \%$ sodium tripolyphosphate.

Although Martín-Sánchez et al. (2009), state that the use of alkaline saline solution during the rinses increases the muscle $\mathrm{pH}$ providing greater solubilization and further elimination of the lipids, in this study, the highest lipid removal occurred when only distilled water was used for the washings. However, there was an effect of the cryoprotectants on the lipid content of the surimis in which only water was used for the washings. In that case, $\mathrm{NaCl}$ and saccharose used as the cryoprotectants contributed to decrease the lipid content. That seems an advantageous matter 
Table 2. Proximate composition (\%), non - nitrogen protein (NNP) (mg N $100 \mathrm{~g}^{-1}$ ) and yield (\%) according to the cryoprotectants and the washings (means \pm standard deviations).

\begin{tabular}{|c|c|c|c|c|}
\hline \multirow[b]{2}{*}{ Analyses } & \multirow[b]{2}{*}{ Cryoprotectant $^{1}$} & \multicolumn{2}{|c|}{ Washings } & \multirow[b]{2}{*}{ Mean } \\
\hline & & 3 washings with distilled water & $\begin{array}{c}1^{\text {st }} \text { washing - } 5 \%, \mathrm{NaHCO}_{3} \\
2^{\text {nd }} \text { and } 3^{\text {rd }} \text { washings - } 3 \% \mathrm{NaCl}\end{array}$ & \\
\hline \multirow{2}{*}{ Moisture } & $\mathrm{C} 1$ & $78.11 \pm 2.45$ & $75.86 \pm 1.95$ & 76.98 \\
\hline & Mean & 77.45 & 74.93 & \\
\hline Ash & $\mathrm{C} 1$ & $1.70 \pm 0.24$ & $1.74 \pm 0.17$ & $1.72^{\mathrm{a}}$ \\
\hline \multirow{3}{*}{ Lipids } & $\mathrm{C} 1$ & $0.38 \pm 0.08^{\mathrm{Bb}}$ & $0.82 \pm 0.19^{\mathrm{A}}$ & 0.60 \\
\hline & $\mathrm{C} 2$ & $0.72 \pm 0.18^{\mathrm{a}}$ & $0.66 \pm 0.11$ & 0.69 \\
\hline & Mean & 0.55 & 0.74 & \\
\hline \multirow[b]{2}{*}{ Proteins } & $\mathrm{C} 1$ & $12.14 \pm 2.22$ & $13.56 \pm 1.01$ & 12.85 \\
\hline & $\mathrm{C} 2$ & $11.38 \pm 1.95$ & $12.43 \pm 1.41$ & 11.91 \\
\hline NNP & Mean & 0.12 & 0.11 & \\
\hline \multirow{3}{*}{ Yield } & $\mathrm{C} 1$ & $68.82 \pm 9.58$ & $61.17 \pm 7.60$ & 65.00 \\
\hline & $\mathrm{C} 2$ & $80.37 \pm 10.73$ & $56.24 \pm 10.99$ & 68.30 \\
\hline & Mean & $74.60^{\mathrm{A}}$ & $58.71^{\mathrm{B}}$ & \\
\hline
\end{tabular}

${ }^{1} \mathrm{C} 1=2 \% \mathrm{NaCl}+1 \%$ Saccharose and $\mathrm{C} 2=5 \%$ Sorbitol $+3 \%$ Sodium tripolyphosphate. Means followed by the same letters within the columns (lower case letters) and the row (capital letters) show significant difference at Tukey`s test $(p<0.05)$.

since these substances have low costs and are easily available for the industry.

Still according to Martín-Sánchez et al. (2009) the use of alkaline salt solutions for the washings also solubilizes the sarcoplasmatic proteins and so facilitates their removal from the muscle. The removal of these proteins is extremely important to avoid their precipitation during heating and the consequent adherence to the myofibrillar proteins, what hinders the gelatinization (Suzuki, 1987). However, in this study, both kinds of washings were equally efficient for the removal of the sarcoplasmatic proteins, originating surimis with the same contents of proteins $(p>0.05)$.

A significant interaction was found between the kinds of washings and the kinds of cryoprotectants on the NNP removal (Table 2), i.e., washings made solely with water and the use of cryoprotectants $\mathrm{NaCl}$ and saccharose (T1) were as efficient as the washings made with salt solutions followed by the addition of cryoprotectants sorbitol and sodium tripolyphosphate (T4) for the removal of the NNP. According to Kirschnik \& Macedo-Viegas (2009), the washing cycles largely remove bacterial enzymes and muscle proteases that can hydrolyze the proteins and, hence, increase the NNP during storage. These authors assigned the decrease in the NNP of the mechanically separated muscle used for the elaboration of the surimi to the leaching of soluble nitrogen substances.

In surimi production, cryoprotectors facilitate the binding of free water with the myofibrillar proteins and provide protection by recovering them, so avoiding their coagulation (Ogawa \& Maia, 1999). So, although the water binding provided by the cryoprotectants could increase the yield, this was not found in this study (Table 2). On the other hand, the kinds of washings exerted a significant influence on yield, with the most favorable results when only distilled water was used for the washings. A higher yield value (84.7\%) was found for the surimi prepared from mechanically separated muscle of tilapia by Kirschnik \& Macedo-Viegas (2009).

Taking into account that the removal of NNP and lipids is deeply important for the final quality of the surimi and that a high yield is equally important, the use of only distilled water for the washings of tilapia muscles aiming at the elaboration of tilapia surimi should be adopted.

\subsection{Color analysis}

The final color of the surimi is due to the loss of lipids, blood, carotenoids and other pigments during the washings of the muscle (Chawla et al., 1996). Thus, Table 3 shows that both kinds of washings were equally efficient $(p>0.05)$ for the removal of colored substances, undesirable for the final color of the product.

High lightness, as the ones found in this study, is desirable by the consumers, since this feature allows the addition of artificial pigments and flavors to the product, thus providing a prompt commercialization (Galvão et al., 2012). Hsu \& Chiang (2002) agree that the surimi with high lightness and low yellowness is preferred by the consumers. These authors found 87.1 for $L$ and 7.5 for $b$ in the surimi made of golden threadfin bream (Nemipterus virgatus) with $78 \%$ moisture and Galvão et al. (2012) found 87.48 for $L, 5.76$ for $b$ and 0.07 for $a$ in the surimi made of piramutaba (Brachyplatystoma vaillantii). 
Table 3. Influence of washings and cryoprotectants on the color parameters ( $L$ - lightness, $A$ - redness, $B$ - yellowness) of the surimi gels (means \pm standard deviations).

\begin{tabular}{crrrrr}
\hline \multirow{2}{*}{ Color parameters } & \multicolumn{4}{c}{ Treatments $^{1}$} \\
\cline { 2 - 5 } & \multicolumn{1}{c}{1} & \multicolumn{1}{c}{3} & \multicolumn{1}{c}{ } & \multicolumn{1}{c}{4} \\
\hline$L$ & $70.82 \pm 2.69$ & $71.26 \pm 0.53$ & $70.02 \pm 2.82$ & $71.49 \pm 1.68$ & 0.7765 \\
$A$ & $2.57 \pm 0.23$ & $2.58 \pm 0.26$ & $2.98 \pm 0.30$ & $2.79 \pm 0.24$ & 0.1294 \\
$B$ & $10.03 \pm 1.00$ & $11.05 \pm 1.53$ & $10.42 \pm 1.02$ & $10.41 \pm 1.44$ & 0.7255 \\
\hline
\end{tabular}

${ }^{1}$ Treatments: 1 (three washings with distilled water / cryoprotectants $2 \% \mathrm{NaCl}$ and $1 \%$ saccharose), 2 (three washings with distilled water / cryoprotectants $5 \%$ sorbitol and $3 \%$ sodium tripolyphosphate), 3 ( $1^{\text {st }}$ washing with $5 \%, \mathrm{NaHCO}_{3} 2^{\text {nd }}$ and $3^{\text {rd }}$ washings with $3 \% \mathrm{NaCl} /$ cryoprotectants $2 \% \mathrm{NaCl}$ and $1 \%$ saccharose $), 4\left(1^{\text {st }}\right.$ washing with $5 \%, \mathrm{NaHCO}_{3} 2^{\text {nd }}$ and $3^{\text {rd }}$ washings with $3 \% \mathrm{NaCl} /$ cryoprotectants $5 \%$ sorbitol and $3 \%$ sodium tripolyphosphate).

Table 4. Influence of washings and cryoprotectants on the texture profile of the surimi gels (means \pm standard deviations and medians).

\begin{tabular}{|c|c|c|c|c|c|c|c|c|}
\hline \multirow{3}{*}{$\begin{array}{l}\text { Texture parameters } \\
\text { Hardness (kgf) }\end{array}$} & \multicolumn{8}{|c|}{ Treatments $^{1}$} \\
\hline & \multicolumn{2}{|c|}{1} & \multicolumn{2}{|c|}{2} & \multicolumn{2}{|c|}{3} & \multicolumn{2}{|c|}{4} \\
\hline & $17.68 \pm 20.66$ & 12.95 & $3.75 \pm 8.78$ & -0.18 & $33.15 \pm 25.16$ & 38.37 & $16.05 \pm 18.70$ & 13.74 \\
\hline Fracturability (kgf) & $5.45 \pm 10.99$ & 0.21 & $23.43 \pm 19.22$ & 23.77 & $15.08 \pm 30.38$ & 0.21 & $24.00 \pm 30.63$ & 15.70 \\
\hline Viscosity & $0.82 \pm 0.09$ & 0.81 & $0.78 \pm 0.08$ & 0.78 & $0.91 \pm 0.03$ & 0.91 & $0.80 \pm 0.18$ & 0.79 \\
\hline Cohesiveness & $0.30 \pm 0.10$ & 0.29 & $0.28 \pm 0.13$ & 0.23 & $0.43 \pm 0.08$ & 0.43 & $0.32 \pm 0.20$ & 0.29 \\
\hline
\end{tabular}

${ }^{1}$ Treatments: 1 (three washings with distilled water / cryoprotectants $2 \% \mathrm{NaCl}$ and $1 \%$ saccharose), 2 (three washings with distilled water / cryoprotectants $5 \%$ sorbitol and $3 \%$ sodium tripolyphosphate), 3 ( $1^{\text {st }}$ washing with $5 \%, \mathrm{NaHCO}_{3} 2^{\text {nd }}$ and $3^{\text {rd }}$ washings with $3 \% \mathrm{NaCl} /$ cryoprotectants $2 \% \mathrm{NaCl}$ and $1 \%$ saccharose), $4\left(1^{\text {st }}\right.$ washing with $5 \%, \mathrm{NaHCO}_{3} 2^{\text {nd }}$ and $3^{\text {rd }}$ washings with $3 \% \mathrm{NaCl} /$ cryoprotectants $5 \%$ sorbitol and $3 \%$ sodium tripolyphosphate).

As the original color of fish muscles varies among species, a comparison of the color parameters found in this study with those found by the cited authors is not suitable. However, even using three washing cycles, Vaz (2005) obtained a tilapia surimi darker $(L=65.26)$ and more yellow $(b=12.84)$ than the ones produced in this study.

\subsection{Texture profile analysis}

The parameters analyzed in the TPA did not significantly vary among the treatments $(p>0.05$, Table 4$)$ but showed high standard deviations, which denotes the lack of homogeneity of the assay. Medina \& Garrote (2002) explained that the gel texture depends on the species of the fish used for the preparation of the surimi, well as on the concentration of the salt used for the proteins solubilization, the temperature, the time of the heat treatment and the moisture content. To Visessanguan et al. (2000), the oscillations in the texture parameters may be due to the breaking of myosin, which leads to an increase in the semi gel fluidity, causing the separation of some protein grids already existent. Still, according to the author, the air inside the gel interferes on the attainment of the TPA since the increase of the pressure accomplished during the test causes the disruption of the structure.

To Barreto \& Beirão (1999), the density and the uniformity of the surimi gel also influence the TPA since only one side of the sample is compressed during the test. Hajidoun \& Jafarpour (2013) found 47.32, 0.80, -1.20 and 0.99 for hardness, cohesivity, adhesivity and elasticity, respectively, for the carpa surimi gel made with $1.5 \%$ chitosan. According to these authors, using chitosan for the surimi preparation decreased the content of heavy chain myosin due to polymerization and, at the same time, increased the formation of cross links among these molecules, so improving the TPA.

\section{Conclusions}

Protein and moisture contents in the surimi were not influenced either by washings or by cryoprotectants, while the ash content was higher when $\mathrm{NaCl}+$ saccharose were the cryoprotectants and the yield was higher when only distilled water was used for the washings. Using distilled water for the washings and $\mathrm{NaCl}$ + saccharose as the cryoprotectants provided the highest lipid and NNP removal. The different treatments produced surimi gels with similar colors and texture. Data provided in this study intend to contribute with the environment by diminishing the impacts caused by the discard of residues in the nature, with the industry by providing a possibility of aggregating value to their products and with the consumer, by providing diversification on the offer for high quality protein products.

\section{Acknowledgements}

Authors acknowledge CAPES for the scholarsh.

\section{References}

Alvarez-Parrilla, E., Puig, A., \& Lluch, M. A. (1997). Preparation and chemical and microstructural characterization of surimi from hake (Merluccius merluccius) and horse mackerel (Trachurus trachurus). Food Science \& Technology International, 3(1), 49-60. http://dx.doi. org/10.1177/108201329700300106.

Barreto, P. L. M., \& Beirão, L. H. (1999). Influência do amido e carragena nas propriedades texturiais de surimi de tilápia (Oreochomis sp). 
Ciência e Tecnologia de Alimentos, 19(2), 183-188. http://dx.doi. org/10.1590/S0101-20611999000200005.

Belibagli, K. B., Speers, R. A., \& Paulson, A. T. (2003). Thermophysical properties of silver hake and mackerel surimi at cooking temperatures. Journal of Food Engineering, 60(4), 439-448. http://dx.doi.org/10.1016/ S0260-8774(03)00067-0.

Burger, J. (2008). Fishing, fish consumption, and awareness about warnings in a university community in central New Jersey in 2007, and comparisons with 2004. Environmental Research, 108(1), 107116. PMid:18632098. http://dx.doi.org/10.1016/j.envres.2008.05.003.

Chawla, S. P., Venugopal, V., \& Nair, P. M. (1996). Gelation of proteins from washed muscle of threadfin bream (Nemipterus japonicus) under mild acidic conditions. Journal of Food Science, 61(2), 362-367. http://dx.doi.org/10.1111/j.1365-2621.1996.tb14194.x.

Fogaça, F. H. S., Otani, F. S., Portella, C. D. G., Santos-Filho, L. G. A., \& Sant'Ana, L. S. (2015). Caracterização de surimi obtido a partir da carne mecanicamente separada de tilápia do Nilo e elaboração de fishburger. Semina: Ciências Agrárias, 36(2), 765-776.

Folch, J., Lees, M., \& Sloane-Stanley, G. H. (1957). A simple method for the isolation and purification of total lipids from animal tissues. The Journal of Biological Chemistry, 226(1), 497-509. PMid:13428781.

Food and Agriculture Organization - FAO. (2016). The state of world fisheries and aquaculture 2016. Part one - World review. Roma: FAO. Retrieved from http://www.fao.org/3/a-i5555e.pdf

Galvão, G. C. D. S., Lourenço, L. D. F. H., Ribeiro, S. D. C. A., Ribeiro, C. D. F. A., Park, K. J., \& Araujo, E. A. F. (2012). Microbiological and physicochemical characterization of surimi obtained from waste of piramutaba fillet. Food Science and Technology, 32(2), 302-307. http://dx.doi.org/10.1590/S0101-20612012005000058.

Hajidoun, H. A., \& Jafarpour, A. (2013). The influence of chitosan on textural properties of common Carp Cyprinus Carpio) Surimi. Journal of Food Processing \& Technolog, 4, 226. http://dx.doi. org/10.4172/2157-7110.1000226.

Horwitz, W., \& Latimer, G. W. Jr. (2006). Official methods of analysis of AOAC International (18th ed.). Gaithersburg: AOAC International.

Hsu, C. K., \& Chiang, B. H. (2002). Effects of water, oil, starch, calcium carbonate and titanium dioxide on the colour and texture of threadfin and hairtail surimi gels. International Journal of Food Science \&
Technology, 37(4), 387-393. http://dx.doi.org/10.1046/j.13652621.2002.00577.x.

Kirschnik, P. G., \& Macedo-Viegas, E. M. (2009). Efeito da lavagem e da adição de aditivos sobre a estabilidade de carne mecanicamente separada de tilápia do Nilo (Oreochromis niloticus) durante estocagem a $-18{ }^{\circ} \mathrm{C}$. Ciência e Tecnologia de Alimentos, 29(1), 200-206. http:// dx.doi.org/10.1590/S0101-20612009000100031.

Kuhn, C. R., \& Soares, G. J. D. (2002). Proteases e inibidores no processamento do surimi. Revista Brasileira de Agrociência, 8, 5-11.

Lee, C. M. (1984). Surimi process technology. Food Technology, 38(11), 69-80.

Lem, A., Bjorndal, T., \& Lappo, A. (2014). Economic analysis of supply and demand for food up to 2030 - Special focus on fish and fishery products (FAO Fisheries and Aquaculture Circular, No. 106). Rome: FAO.

Martín-Sánchez, A. M., Navarro, C., Pérez-Álvarez, J. A., \& Kuri, V. (2009). Alternatives for efficient and sustainable production of surimi: a review. Comprehensive Reviews in Food Science and Food Safety, 8(4), 359-374. http://dx.doi.org/10.1111/j.1541-4337.2009.00087.x.

Medina, J. R., \& Garrote, R. L. (2002). The effect of two cryoprotectant mixtures on frozen surubí surimi. Brazilian Journal of Chemical Engineering, 19(4), 419-424. http://dx.doi.org/10.1590/S010466322002000400010 .

Ogawa, M., \& Maia, E. L. (1999). Manual de pesca: ciência e tecnologia do pescado. São Paulo: Varela.

Park, J. W. (2014). Surimi and surimi seafood (3rd ed.). Boca Raton: CRC Press. Retrieved from https://books.google.com.br/books?h

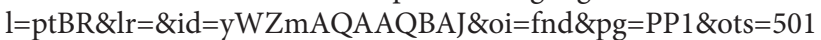
wpq3BVc\&sig=RvrMUmAPCUxQCN2bSlvXPNzyYQk\#v=onep age\&q\&f=false

Suzuki, T. (1987). Tecnologia de las proteínas de pescado y krill. Zaragoza: Acribia.

Vaz, S. K. (2005). Elaboração e caracterização de linguiça fresca "tipo toscana" de tilápia (Oreochromis niloticus) (Dissertação de mestrado). Universidade Federal do Paraná, Curitiba.

Visessanguan, W., Ogawa, M., Nakai, S., \& An, H. (2000). Physicochemical changes and mechanism of heat-induced gelation of arrowtooth flounder myosin. Journal of Agricultural and Food Chemistry, 48(4), 1016-1023. PMid:10775343. http://dx.doi.org/10.1021/jf9900332. 